\title{
Correction to: An English-language adaptation and validation of the Political Efficacy Short Scale (PESS)
}

\author{
Katharina Groskurth", Désirée Nießen, Beatrice Rammstedt and Clemens M. Lechner
}

Correction to: Measurement Instruments for the Social Sciences 3, 1 (2021)

https://doi.org/10.1186/s42409-020-00018-z

The original article (Groskurth et al., 2021) contained minor errors in the ESM, Table 2, and Material section which have since been corrected.

Published online: 23 February 2022

\footnotetext{
Reference

Groskurth, K., et al. (2021). An English-language adaptation and validation of the Political Efficacy Short Scale (PESS). Measurement Instruments for the Social Sciences., 3, 1 https://doi.org/10.1186/s42409-020-00018-z.
}

The original article can be found online at https://doi.org/10.1186/s42409020-00018-z.

*Correspondence: katharina.groskurth@gesis.org

GESIS - Leibniz Institute for the Social Sciences, P.O. Box 1221 55,

68072 Mannheim, Germany

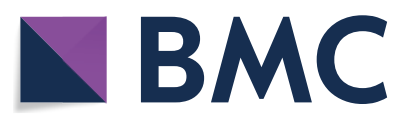

(c) The Author(s) 2022. Open Access This article is licensed under a Creative Commons Attribution 4.0 International License, which permits use, sharing, adaptation, distribution and reproduction in any medium or format, as long as you give appropriate credit to the original author(s) and the source, provide a link to the Creative Commons licence, and indicate if changes were made. The images or other third party material in this article are included in the article's Creative Commons licence, unless indicated otherwise in a credit line to the material. If material is not included in the article's Creative Commons licence and your intended use is not permitted by statutory regulation or exceeds the permitted use, you will need to obtain permission directly from the copyright holder. To view a copy of this licence, visit http://creativecommons.org/licenses/by/4.0/. 